surgery-associated acute kidney injury: A prospective cohort study / Haase M., Bellomo R., Matalanis G., [et al.] // J Thorac Cardiovasc Surg - 2009. - № 138. - P. 1370-1376.

4. Jyrala A. Effect of mild renal dysfunction (s-creat $1.2-2.2 \mathrm{mg} / \mathrm{dl}$ ) on presentation characteristics and short- and long-term outcomes of on-pump cardiac surgery patients / Jyrala A., Weiss R. E., Jeffries R. A., [et al.] // Interactive Cardiovascular and Thoracic Surgery - 2010. - № 10. - P. 777-782.

5. Kidney Disease: Improving Global Outcomes (KDIGO) Acute Kidney Injury Work Group. KDIGO Clinical Practice Guideline for Acute Kidney Injury. Kidney Int. - 2012. - Suppl. 2. $138 \mathrm{p}$.

6. Kuan $Y$. GFR prediction using the MDRD and Cockcroft and Gault equations in patients with end-stage renal disease / Kuan Y., Hossain M., Surman J., [et al.] // Nephrol Dial Transplant 2005. - № 20. - P. 2394-2401.
7. National Kidney Foundation. K/DOQI Clinical Practice Guidelines for Chronic Kidney Disease: Evaluation. Classification and Stratification. - Am J Kidney Dis - 2002. - Suppl 1. - 266 p.

8. Perez-Valdivieso J. R. Cardiac-surgery associated acute kidney injury requiring renal replacement therapy. A Spanish retrospective case-cohort study / Perez-Valdivieso J. R., Monedero P., Vives M., [et al.] // BMC Nephrology - 2009. - № 10. P. 27-31.

9. Van Wert $R$. High-dose renal replacement therapy for acute kidney injury: Systematic review and meta-analysis / Van Wert R., Friedrich J. O., Scales D. C., [et al.] // Crit Care Med - 2010. - № 38. P. 57-65.

Надійшла до редакції 15.02.2016 Прийнята до друку 23.02.2016

(C) Багдасарова I. В., Круглікова І. В., Корніліна О. М., В. Т. Кругліков, 2016

УДК 616.611-002-036.12+616.637]-053.2-08:615.37

І. В. БАГДАСАРОВА, І. В. КРУГЛІКОВА, О. М. КОРНІЛІНА, В. Т. КРУГЛІКОВ

НЕСПЕЦИФІЧНІ ФАКТОРИ ЗАХИСТУ ТА МЕДІАТОРИ ЗАПАЛЕННЯ СЕЧІ ДІТЕЙ, ХВОРИХ НА ГЛОМЕРУЛОНЕФРИТ, ЗА НАЯВНОСТІ ГЕРПЕСВІРУСНОЇ ІІНФЕКЦӤ. ПОВІДОМЛЕННЯ І. ВИЗНАЧЕННЯ РІВНЯ SIGA ТА МСР-1

\author{
I. BAGDASAROVA, I. KRUGLIKOVA, E. KORNILINA, V. KRUGLIKOV
}

\title{
NON-SPECIFIC PROTECTION FACTORS AND INFLAMMATORY MEDIATORS IN URINE OF CHILDREN WITH GLOMERULONEPHRITIS IN THE PRESENCE OF HERPESVIRAL INFECTION. NOTICE I. DETERMINATION OF SIGA AND MCP-1
}

$$
\begin{aligned}
& \text { ДУ « Інститут нефрології НАМН України», м. Київ } \\
& \text { SI “Institute of Nephrology of NAMS of Ukraine”, Kyiv }
\end{aligned}
$$

Ключові слова: імунологічні показники сечі, герпесвірусна інфекція, гломерулонефрит, діти.

Key words: immunological indexes of urine, herpesviral infection, glomerulonephritis, children

Резюме. Целью работы было изучение показателей, характеризующих местный иммунитет, у больных с различными формами гломерулонефрита при наличии герпесвирусной инфекции.

Материалы и методы. Проведена количественная оценка содержания SIgA и МСР-1 в моче 47 больных гломерулонефритом и 10 условно здоровых лии.

Результаты исследования. У больных с гломерулонефритом наблюдалось снижение уровня SIgA и достоверное повышение уровня МСР-1 в моче. Значительное увеличение уровня данных показателей отмечено у больных с гормонорезистентным вариантом нефротической формы гломерулонефрита; у пациентов с тяжелым течением заболевания, а также при отсутствии ремиссии. В большей степени такие изменения выявлены у детей с активной (реактивированной) герпесвирусной инфекцией.

Заключение. Подчеркнута важность изучения

Корніліна Олена Михайлівна elenkorni@mail.ru иммунологических показателей в моче больных с гломерулонефритом для характеристики иммунопатологического процесса в почке и прогноза течения заболевания. 
Summary. The aim of this work was the study of indicators characterizing the local immunity in patients with various forms of glomerulonephritis by presence of herpesviral infection.

Materials and methods. A quantitative estimation of the content of SIgA and MCP-1 in urine of 47 patients with glomerulonephritis and 10 apparently healthy individuals was conducted.

Results. The decrease of SIgA level and reliable increase of MCP-1 level were observed in urine of patients with glomerulonephritis. There was a significant increase in the level of these indices in hormone-resistant patients with nephrotic form of glomerulonephritis; in patients with severe course of the disease and also in the absence of remission. More such changes were found in children with active (reactivated) herpesviral infections.

Conclusion. There has been confirmed the importance of the study of immunologic parameters in the urine of patients with glomerulonephritis to characterize immunopathological process in the kidney and prognosis of the disease.

ВСТУП. Гломерулонефрит (ГН) є одним 3 найбільш частих захворювань, що приводять до розвитку хронічної ниркової недостатності і ранньої інвалідизації. У зв'язку з цим актуальним є продовження пошуку етіологічних та патогенетичних факторів, що сприяють частому рецидивуванню захворювання, торпідному перебігу, формуванню гормонозалежних та гормонорезистентних форм ГН у хворих.

Важливим механізмом розвитку ГН є відкладення в клубочках нирок імунних комплексів, які включають імуноглобуліни, компоненти комплементу і різні антигени, в тому числі, і вірусні. Більшість досліджень присвячено вивченню ролі гепатиту В в патогенезі та етіології ГН [2, 19], але в останні роки все більшу увагу приділяють герпесвірусній інфекції (ГВI), що обумовлена вірусами простого герпесу 1-го та 2-го типів (ВПГ ), цитомегаловірусом (ЦМВ) та вірусом Епштейна-Барр (ВЕБ) [6, 9]. За даними Ігнатової М.С. при вірусологічному дослідженні морфобіоптатів ниркової тканини ВПГ-1 визначався в канальцевих структуpax, ЦМВ - в клубочках і в канальцях, але в більшій мірі виявлялися антигени ВЕБ, що свідчило про активне утворення і відкладення ВЕБ-імунних комплексів в клубочках нирок [3]. Частіше ВПГ-1 та ЦМВ виявлялися в різних матеріалах (кров, сеча, слина) від дітей, хворих на ГН, ніж у дітей без ниркової патології, а також від хворих на пієлонефрит. Виявлена при герпесвірусних інфекціях вірусемія часто співпадала 3 початком клінічного загострення захворювання, тому було зроблено висновок, що вказані віруси мають відповідне патогенетичне значення в розвитку та прогресуванні ГН [1].

Віруси, які в латентному стані присутні в різних органах людини, стають більш активними по мірі поліпшення антимікробної терапії та зниження імунного захисту у великих груп людської популяції. Особливо чутливими в цьому відношенні $€$ діти, тому що саме в них слабким може бути імунний захист у зв язку з його недостатнім розвитком в перші роки життя або пригніченням внаслідок несприятливих зовнішніх чинників (екологічних, ультрафіолетового опромінення, пневмококової та стрептококової інфекції, застосування імуносупресивних ліків, тощо), що може призводити до рецидивування ГВI. Характерними змінами імунного статусу при герпесвірусній інфекції, в тому числі і вірусасоційованому гломерулонефриті у дітей, є зниження продукції інтерферону, пригнічення фагоцитарної функції клітин, дисрегуляція системи інтерлейкінів. Захист організму проти вірусів як правило пов'язаний з гуморальним (імуноглобулін А) та клітинним імунітетом (мононуклеарні клітини). Проте дослідження системного імунітету не може дати повної інформації про етіопатогенез гломерулонефриту і виникає необхідність визначення ролі факторів місцевого імунітету, оскільки відомо, що у хворих на ГН в нирковій тканині виявляються антигени ВПГ-1 як у клубочках, так і в тубулярному епітелії [4, 15], що вказує на те, що для ГВІ переважаючим є як імунокомплексний механізм, так і пошкодження нефротелію вірусом з розвитком тубулоінтерстиціального компонента. Переважання тубулоінтерстиціальних ушкоджень встановлено і у дітей з вродженою цитомегаловірусною інфекцією [16].

Матеріальну основу місцевого імунітету складають антитіла, які відносяться до особливої форми імуноглобуліну А - секреторного (sIgA). Секреторний $\operatorname{IgA}$, забезпечуючи «першу лінію захисту» слизової оболонки, діє як аглютинатор мікроорганізмів і нейтралізатор токсинів, інгібуючи зв язування вірусів і бактерій з поверхнею слизових оболонок. Секреторний IgA (дімерний та полімерний) має більше антигензв'язуючих ділянок (відповідно 4 та 8) в порівнянні з мономерною сироватковою формою $\operatorname{IgA}$ й тому здатний більш ефективно нейтралізувати віруси, бактеріальні токсини, ферменти й аглютинувати бактерії. Секреторний $\operatorname{IgA}$ проявляє активність у біологічних середовищах з високим змістом протеолітичних ферментів і його резистентність до дії протеолітичних ферментів обумовлена секреторним компонентом [7].

Виняткова важливість sIgA-антитіл у противірусному захисті обумовлена тим, що вони із самого початку присутні в місцях первинного контакту вірусу з епітеліальними клітинами слизових оболонок організму хазяїна, здатні частково блокувати процеси адгезії до епітеліальних клітин слизових оболонок не тільки вірусних частинок, але й бактеріальних організмів [20].

У високих концентраціях sIgA-антитіла блокують прикріплення вірусу до клітинної стінки, у низьких здатні пригнічувати клітинну реплікацію вірусу, не впливаючи на його адгезивні властивос- 
ті. Зниження рівня sIgA призводить до хронічної патології. Низький рівень цього імуноглобуліну може бути пов язаний з гнітючою дією вірусів на його синтез або виснаженням його продукції в умовах частого впливу вірусних інфекцій. Залишається нез'ясованим участь секреторного IgA у розвитку ГН; завдяки визначенню рівня sIgA в сечі можна визначити інтенсивність його локального синтезу при запальній реакції в нирках.

У хворих на ГН, в тому числі асоційований з ГВI, відкладення імунних комплексів в нирці або ïx утворення in situ $€$ пусковим механізмом для ланцюга запальних реакцій - після початкового ушкодження нирок відбувається активація комплементу, інфільтруючих імунних і резидентних клітин тканини органу і виділення великої кількості медіаторів запалення (протеолітичних ферментів, хемокінів, різних цитокінів і факторів росту), залучення циркулюючих лейкоцитів та ін. [13]. Серед хемокінів, які контролюють міграцію різних видів лейкоцитів, найбільш сильну хемотаксичну активність проявляє моноцитарний хемоаттрактантний протеїн (monocyte chemoattractant protein-1, MCP1), який також вважається ключовим в патогенезі тубулоінтерстиціальних змін в нирці [10]. МСР-1 експресується переважно тубулярним епітелієм, а також мононуклеарними клітинами в зонах інтерстиціального запалення та ендотелієм судин інтерстицію. Саме цей цитокін є головним тригером, який забезпечує міграцію, адгезію і активацію мононуклеарних клітин, які виділяють комплекс прозапальних цитокінів (ФНП- , ІЛ-6, ІЛ-8); сприяє підвищенню активованих моноцитів/макрофагів поряд 3 канальцевими епітеліальними клітинами, ушкоджуючи їх; стимулює секрецію основного профіброгенного цитокіну - трансформуючого фактору росту (ТФР- 1). В умовах підвищеної продукції ТФР-1 відбувається трансформація резидентних фібробластів в міофібробласти, які володіють спроможністю продукувати у великій кількості компоненти екстрацелюлярного матріксу [11], що лежить в основі склеротичних змін паренхіми. Отже, в даний час є підстави припустити, що тубулоінтерстиціальна поразка є істотним чинником прогресування як первинно інтерстиціальних, так і гломерулярних захворювань.

Метою нашої роботи було вивчення стану місцевого імунітету при дослідженні факторів імунного захисту та медіаторів запалення (рівнів $\operatorname{sgA}$ та МСР-1) в сечі дітей з різними клінічними варіантами гломерулонефриту, в тому числі за наявності активної герпесвірусної інфекції, та встановити їх вплив на важкість та перебіг захворювання.

МАТЕРІАЛ ТА МЕТОДИ ДОСЛІЛЖЕННЯ. Було обстежено 47 дітей, хворих на ГН, віком від 3 до 18 років (в середньому 11,4 $\pm 1,2$ років), з яких у 24 діагностована нефротична форма (НФ), у решти 23 дітей - гематурична форма (ГФ) гломерулонефриту. Клінічну верифікацію діагнозу проведено згідно прийнятої в Україні класифікації первинного ГН у дітей (м. Вінниця, 1976). Пацієнти отримували терапію ГН згідно протоколу, затвердженого МО3 України [12]. Відповідь на терапію класифікували як: ремісія (повна ремісія - нормалізація біохімічних показників та аналізів сечі; часткова ремісія - покращення біохімічних показників, зменшення протеїнурії <2 г/доба при НС, значне зменшення або ліквідація гематурії при ГФ); відсутність ремісії (відсутність ефекту впродовж 3-х і більше місяців - збереження активності НС або ступеню гематурії при ГФ, рецидив ГН). Хворі з НФ додатково розподілені на стероїдочутливих (СЧ) та стероїдорезистентних (СР) залежно від чутливості до глюкокортикостероїдів на 6-му тижні терапії. 3 числа всіх обстежених хворих у 28 пацієнтів відзначалась відсутність ремісії; 19 хворих знаходились в стадії клініко-лабораторної ремісії; за тяжкістю перебігу хвороби всі хворі були розподілені на дві групи - 3 тяжким перебігом (тривалий генералізований набряковий синдром, некорегована артеріальна гіпертензія, порушення функції нирок, наявність ускладнень з боку інших органів, $n=18$ ) та середньої тяжкості (швидка ліквідація набрякового синдрому, відсутність тривалої гіпертензії, нормальна функція нирок, перебіг без ускладнень з боку інших органів, n=29). За допомогою методів імуноферментного аналізу (IФА) та полімеразної ланцюгової реакції (ПЛР) у 37 хворих дітей виявлено активну (реактивовану) ГВІ. До ГВІ відносили одну або декілька найбільш поширених інфекцій, а саме обумовлених ВПГ 1/2, ЦМВ та ВЕБ. Контрольну групу склали 10 умовно здорових дітей відповідного віку.

В ІФА кількісно визначали рівень специфічних IgG та IgM в сироватці крові за допомогою тест-систем фірми DRG (Німеччина). За діагностично значимі рівні IgG, що відображали активну (реактивовану) ГВI, приймали титр антитіл, що перевищував «норму» в 4 і більше разів $[5,17]$. ПЛР проводили за допомогою тест-систем АмплиСенс (Росія), використовуючи осад клітин сечі [17], в якому виявляли ДНК герпесвірусів. Кількісне визначення $\operatorname{sgA}$ та MCP-1 у ранковій сечі проводилось за методом ІФА з використанням наборів реактивів фірм «Хема» (Росія) та Bioscience (Австрія).

Статистичну обробку результатів дослідження проводили з використанням Microsoft Office Excel 2003 for Windows та STATISTICA 6.0 [8, 14]. Було встановлено, що значення SIgA та MCP-1 у сечі умовно здорових дітей та дітей, хворих на ГН, не підпорядковувались закону нормального розподілу, тому використовували непараметричні методи статистики - для кожного показника обчислювали медіану (Ме), 25 та 75 перцентілі (25-75\%), а для ïx коректного порівняльного аналізу - U-критерій Манна-Уітні. Для кореляційного аналізу використовували ранговий коефіціент Спірмена ( $\rho)$ та таукоефіціент Кендалла $(\tau)$. Статистично значущими вважали відмінності з $\mathrm{p}<0,05$. 
РЕЗУЛЬТАТИ ДОСЛІДЖЕННЯ ТА ЇХ ОБГОВОРЕННЯ. У дітей, хворих на ГН, спостерігалось зниження рівня SIgA в сечі порівняно до здорових осіб, проте за наявності ГВІ в деяких хворих $(\mathrm{n}=5)$ відмічено навіть суттєве його підвищення (до 2,12-4,9 мкг/мл), що сприяло зростанню ін- терквартільного діапазону (табл. 1). Ймовірно, підвищення секреторного IgA пов'язано з тим, що він є важливим компенсаторним резервом організму, який забезпечує захист від вірусів та сприяє елімінації збудників.

Таблиия 1

Рівень sIgA в сечі хворих з різними клінічними формами ГН, в залежності від чутливості до гормонів, перебігу та тяжкості захворювання

\begin{tabular}{|c|c|c|c|}
\hline \multirow{2}{*}{ Групи обстежених } & \multirow{2}{*}{ n } & \multicolumn{2}{|c|}{ Рівень SIgA, х10-2 мкг/мл } \\
\hline & & Me & $25 \%-75 \%$ \\
\hline Контрольна група & 9 & 15,0 & $3,1-40,0$ \\
\hline Хворі на ГН - заг. група & 47 & 1,7 & $1,0-17,0$ \\
\hline-3 ГВІ & 37 & 1,9 & $1,0-17,8$ \\
\hline - без ГВI & 10 & $1,8 *$ & $1,2-2,3$ \\
\hline \multicolumn{4}{|l|}{ Варіанти клінічного перебігу } \\
\hline Хворі на ГН, НФ - заг. група & 24 & 1,8 & $1,2-19,4$ \\
\hline-3 ГВІ & 19 & 3,3 & $1,2-37,5$ \\
\hline - без ГВI & 5 & $1,6 *$ & $1,2-1,8$ \\
\hline Хворі на ГН, ГФ - заг. група & 23 & 1,8 & $0,7-17,0$ \\
\hline-3 ГВІ & 18 & $1,5 *$ & $0,2-13,8$ \\
\hline - без ГВI & 5 & 2,0 & $1,8-17,0$ \\
\hline \multicolumn{4}{|l|}{ Чутливість до гормонів } \\
\hline Хворі з НФ, стероїдочутливі - заг. гр. & 12 & $1,6 *$ & $1,0-4,6$ \\
\hline - 3 ГВІ & 9 & $1,6 *$ & $0,9-7,0$ \\
\hline Хворі з НФ, стероїдорезистентні - заг. гр. & 12 & $9,7^{*}$ & $1,6-129,0$ \\
\hline - 3 ГВІ & 10 & $19,4^{*}$ & $1,7-220,0$ \\
\hline \multicolumn{4}{|l|}{ Перебіг гломерулонефриту } \\
\hline Ремісія - заг. група & 19 & $1,6 *$ & $0,7-7,2$ \\
\hline-3 ГВІ & 15 & $1,0 *$ & $0,8-8,3$ \\
\hline - без ГВІ & 4 & $1,7 *$ & $1,4-1,8$ \\
\hline Відсутність ремісії - заг. група & 28 & $3,2 \cdot$ & $1,4-29,7$ \\
\hline-3 ГВІ & 22 & $3,5 \cdot$ & $1,4-36,7$ \\
\hline - без ГВI & 6 & 2,2 & $1,0-17,0$ \\
\hline \multicolumn{4}{|l|}{ Тяжкість перебігу } \\
\hline Тяжкий - заг. група & 18 & $11,6^{\nabla}$ & $1,7-65,0$ \\
\hline-3 ГВІ & 16 & $11,6^{\nabla}$ & $1,7-142,5$ \\
\hline Середньої тяжкості - заг. група & 29 & $1,4 *$ & $0,8-3,7$ \\
\hline-3 ГВІ & 21 & $1,4 *$ & $0,7-8,3$ \\
\hline - без ГВI & 8 & $1,7 *$ & $1,1-1,9$ \\
\hline
\end{tabular}

Примітки: 1. * - достовірні відмінності $(\mathrm{p}<0,05)$ відносно групи контролю;

2. - достовірні відмінності $(\mathrm{p}<0,05)$ відносно відповідної групи стероїдочутливих хворих;

3. - - достовірні відмінності $(\mathrm{P}<0,05)$ відносно групи хворих з ремісією;

4. $\nabla$ - достовірні відмінності $(\mathrm{P}<0,05)$ відносно групи хворих з перебігом середньої тяжкості 
В цілому по групі не було встановлено відмінностей при порівнянні рівня $\operatorname{sgA}$ в сечі від хворих 3 різними клінічними формами ГН. Проте аналіз хворих в залежності від наявності ГВІ показав незначне перебільшення медіани для sIgA у хворих з НФ та 3 ГВІ порівняно до хворих з гематурією. I навпаки, Хворі без ГВІ з НФ мали достовірно низький (відносно контролю) вміст у сечі $\operatorname{sgA}$, а з ГФ - відмічено його зростання. Аналіз результатів щодо рівня SIgA у хворих з НФ виявив, що підвищення показника спостерігалось у хворих з стероїдорезистентним варіантом, і особливо у хворих на ГН за наявності ГВІ. Високий вміст sIgA у СР хворих вказує на дисбаланс в імунній системі і може розглядатися як прояв хронічного запального процесу, до якого, ймовірно, приєднався ще й аутоімунний компонент.

В сечі хворих дітей в стадії ремісії медіана для sIgA була достовірно зниженою відносно контролю, тільки міжквартільний діапазон показника у дітей з ГВІ був більшим, ніж у хворих без ГВІ, що вказує на відповідну імунну реакцію з боку В-клітин слизової нирки. Відсутність ремісії у хворих на ГН супроводжувалась достовірним збільшенням рівня sIgA відносно хворих в стадії ремісії, в першу чергу, за рахунок хворих з ГВІ, що підтверджує посилення компенсаторних механізмів місцевого імунітету для перешкоджання адгезії вірусів на клітинах ниркової тканини.

Тяжкість перебігу захворювання характеризувалась підвищенням величини медіани для sIgA у сечі в порівнянні до хворих з перебігом середньої тяжкості, у яких цей показник залишався достовірно зниженим відносно норми. Наявність ГВІ сприяла підвищенню міжквартільного діапазону для $\operatorname{sgA}$ - у 25\% таких дітей рівень даного імуноглобуліну перевищував 1,42 мкг/мл.

Таким чином, знижений в цілому у хворих на ГН рівень секреторного IgA частіше підвищувався у пацієнтів з нефротичною формою і з виявленою ГВІ, в першу чергу, у стероїдорезистентних пацієнтів. Зростання рівня SIgA спостерігалось у пацієнтів за відсутності ремісії і часто тяжким перебігом ГН, при цьому в більшій мірі у хворих з ГВI.

Проведені дослідження щодо концентрації МCP-1 у сечі хворих на ГН показали, що у всіх хворих дітей рівень даного хемокіну був достовірно вищим, ніж у здорових осіб, а наявність ГВІ сприяла підвищенню МСР-1 (виявлена тенденція до зростання) (табл. 2). Коливання концентрації МСР-1 у хворих з ГВІ спостерігалось в межах від 46 пг/мл до 2880 пг/мл, в групі порівняння (без ГВІ) - від 62,4 пг/мл до 552,0 пг/мл.

Таблиия 2

Рівень МСР-1 в сечі хворих з різними клінічними формами ГН, в залежності від чутливості до гормонів, перебігу та тяжкості захворювання

\begin{tabular}{|c|c|c|c|}
\hline \multirow{2}{*}{ Групи обстежених } & \multirow{2}{*}{$\mathbf{n}$} & \multicolumn{2}{|c|}{ Рівень МСР-1, пг/мл } \\
\hline & & Me & $25 \%-75 \%$ \\
\hline Контрольна група & 8 & 58,0 & $52,7-95,2$ \\
\hline Хворі на ГН - заг. група & 47 & $188,0 *$ & $106,0-552,0$ \\
\hline-3 ГВІ & 37 & $213,6 *$ & $132,0-552,0$ \\
\hline - без ГВI & 9 & $98,4 *$ & $76,8-292,0$ \\
\hline \multicolumn{4}{|l|}{ Варіанти клінічного перебігу } \\
\hline Хворі на ГН, НФ - заг. група & 24 & $176,0 *$ & $87,6-680,0$ \\
\hline-3 ГВІ & 19 & 232,0 * & $106,0-720,0$ \\
\hline - без ГВI & 5 & $76,8 \cdot$ & $64,0-98,4$ \\
\hline Хворі на ГН, ГФ - заг. група & 22 & $200,8 *$ & $132,0-292,0$ \\
\hline-3 ГВІ & 18 & $200,8 *$ & $148,0-272,0$ \\
\hline - без ГВI & 4 & $206,0 *$ & $108,0-302,0$ \\
\hline \multicolumn{4}{|l|}{ Чутливість до гормонів } \\
\hline Хворі з НФ, стероїдочутливі - заг. гр. & 12 & $102,2 *$ & $76,0-174,0$ \\
\hline - 3 ГВІ & 9 & $132,0 *$ & $98,4-184,0$ \\
\hline Хворі з НФ, стероїдорезистентні - заг. гр. & 12 & $612,0 * *$ & $344,0-804,0$ \\
\hline - 3 ГВІ & 10 & $680,0 * *$ & $520,0-888,0$ \\
\hline \multicolumn{4}{|l|}{ Перебіг гломерулонефриту } \\
\hline Ремісія - заг. група & 19 & $148,0 *$ & $98,4-213,6$ \\
\hline-3 ГВІ & 15 & $152,0 *$ & $102,0-213,6$ \\
\hline - без ГВI & 4 & 87,6 & $70,4-195,2$ \\
\hline
\end{tabular}


Продовження табл. 2

\begin{tabular}{|c|c|c|c|}
\hline \multirow{2}{*}{ Групи обстежених } & \multirow{2}{*}{$\mathbf{n}$} & \multicolumn{2}{|c|}{ Рівень МСР-1, пг/мл } \\
\hline & & Me & $25 \%-75 \%$ \\
\hline Відсутність ремісії - заг. група & 27 & $272,0 *$ & $132,0-672,0$ \\
\hline-3 ГВІ & 22 & $335,2 *$ & $168,0-688,0$ \\
\hline - без ГВI & 5 & $120,0 *$ & $96,0-312,0$ \\
\hline \multicolumn{4}{|l|}{ Тяжкість перебігу } \\
\hline Тяжкий - заг. група & 17 & $552,0 * \nabla$ & $176,0-720,0$ \\
\hline - 3 ГВІ & 16 & $536,0 * \nabla$ & $172,0-804,0$ \\
\hline Середньої тяжкості - заг. група & 29 & $148,0 *$ & $98,4-232,0$ \\
\hline-3 ГВІ & 21 & $152,0 *$ & $106,0-232,0$ \\
\hline - без ГВI & 8 & 97,2 & $70,4-206,0$ \\
\hline
\end{tabular}

Примітки: 1. * - достовірні відмінності $(\mathrm{p}<0,05)$ відносно групи контролю;

2. - достовірні відмінності $(\mathrm{p}<0,05)$ відносно групи хворих з ГВІ

3. - достовірні відмінності $(\mathrm{p}<0,05)$ відносно відповідної групи стероїдочутливих хворих;

4. - - достовірні відмінності $(\mathrm{P}<0,05)$ відносно групи хворих з ремісією;

5. $\nabla$ - достовірні відмінності $(\mathrm{P}<0,05)$ відносно групи хворих з перебігом середньої тяжкості

При порівнянні хворих дітей в залежності від клінічного варіанту ГН спостерігалось незначне перевищення рівня МСР-1 у хворих з НФ порівняно до хворих з гематурією, хоча у половини пацієнтів з НФ ГН рівень МСР-1 був нижче (медіана становила 176,0 пг/мл), ніж у хворих з ГФ (Ме=200,8 пг/мл), в той же час інтерквартільний діапазон був вище і дорівнював 87,6-680,0 пг/мл. Медіани для МСР-1 серед хворих с НФ та гематурією і з ГВІ майже не відрізнялися між собою, але мали достовірні відмінності порівняно до контрольної величини. Коливання концентрацій МСР-1 у хворих 3 ГФ і з ГВІ мало відрізнялися від таких у хворих без виявленої інфекції. В той же час хворі діти з НФ ГН та з ГВІ мали достовірно підвищений рівень хемокіну в сечі, ніж хворі без ГВI, що може усугубляти перебіг захворювання та провокувати його прогресування.

Більш детальний аналіз отриманих результатів щодо рівня МСР-1 у хворих на ГН з НФ показав, що у хворих з стероїдочутливою формою медіана концентрації МСР-1 та інтерквартільний діапазон були достовірно нижче, ніж аналогічні показники у хворих з стероїдорезистентним варіантом НФ. Таке суттєве зниження рівня МСР-1 в сечі СЧ хворих, йомовірно, обумовлено більш значним, ніж у СР хворих, пригніченням транскрипції його генів в проксимальних канальцевих клітинах під впливом стероїдних препаратів [18], оскільки згідно сучасним уявленням останні чинять антихемокінову дію через вплив на ядерний фактор NF-kB [21]. Збереження високої концентрації МСР-1 в сечі СР хворих свідчить про продовження запального процесу і необхідність корекції схеми лікування. Зростання вмісту хемокіну в сечі спостерігалось знов за рахунок хворих на ГН з ГВІ.
Для встановлення можливої участі МСР-1 в прогресуванні ГН був проведений аналіз результатів в залежності від перебігу захворювання та його тяжкості. Представлені в таблиці 2 дані свідчать, що хворі на ГН навіть в стадії часткової ремісії мали підвищений $(\mathrm{p}<0,05)$ рівень МСР-1 в сечі в порівнянні з групою контролю. У хворих дітей за відсутності ремісії даний показник достовірно перевищував не тільки показник групи контролю, а й групи хворих з ремісією. За наявності ГВІ спостерігалось зростання рівня МСР-1 в обох групах, в більшій мірі у хворих за відсутності ремісії. Слід зазначити, що відсутність ремісії встановлено у 12 $(44,4 \%)$ хворих з НФ та у $15(55,6 \%)$ з ГФ, при цьому ГВІ виявлена в $22(81,5 \%)$ випадках; часткова ремісія відмічена у $12(63,2 \%)$ пацієнтів з НФ і у 7 $(36,8 \%)-3$ ГФ, ГВІ при цьому виявлена у $15(78,9$ \%) хворих.

Тяжкість перебігу захворювання характеризувалась достовірним збільшенням рівня МСР-1 в сечі як відносно здорових осіб, так і хворих з перебігом середньої тяжкості. Наявність ГВІ забезпечувало достовірне зростання рівня МСР-1 відносно контролю, в той же час у хворих без ГВІ рівень хемокіну був нижче і не мав достовірної різниці 3 контролем.

Отже, у дітей з тяжким перебігом ГН та за відсутності ремісії, а також з резистентною до гормонотерапії формою захворювання спостерігалось зростання рівня МСР-1 в сечі, що підтверджує вище доведену думку щодо виникнення дисбалансу в системі місцевого імунітету на тлі хронізації запального процесу в нирках. Найбільше відхилення рівня даного хемокіну від контролю відмічено у дітей з нефротичною формою ГН та 3 виявленою активною (реактивованою) ГВІ. Підвищення 
рівня МСР-1 в сечі у хворих на ГН буде сприяти підтриманню запалення у разі як інтерстиціального, так і гломерулярного пошкодження нирок і призводити до подальшого прогресування захворювання. Отже, отримані результати свідчать про важливу роль хемокіну МСР-1 в імунопатогенезі ГН як свідка та учасника імунної відповіді. Високі концентрації МСР-1 в сечі хворих на ГН можна розглядати як маркер напруги імунної системи в процесі хронізації захворювання.

Встановлено кореляційний зв'язок вмісту МСР-1 з рівнем sIgA в сечі хворих дітей $(=0,46$, $\mathrm{p}=0,001 ;=0,32, \mathrm{p}=0,001)$. У хворих на ГН без ГВІ виявлений зв'язок характеризувався більшим коефіцієнтом кореляції $(\rho=0,89, \mathrm{p}=0,0005 ; \tau=0,76$, $\mathrm{p}=0,001)$, ніж у хворих, в яких була виявлена ГВІ $(\rho=0,38, p=0,022 ; \tau=0,26, p=0,024)$. Виявлена позитивна кореляція між показниками свідчить про участь обох факторів в системі формування місцевого імунітету у відповідь на пошкодження ниркової тканини, в тому числі обумовленої герпесвірусами. Відомо, що хемокіни поряд з основною роллю в процесах міграції клітин володіють захисною дією проти інфекційних агентів (бактерій, вірусів), тому разом з секреторним IgA MCP-1 може чинити захисну дію, проте занадто високий рівень буде призводити до негативного ефекту, оскільки МСР-1 стимулює синтез профіброгенного цитокіну ТФР- $\beta$. Наявність ГВІ призводила до дисбалансу в системі імунологічного захисту. Високий рівень МСР-1 у частини хворих не завжди співпадав з підвищенням рівня sIgA, на що вказує зменшення сили кореляційного зв'язку. Підтвердженням цього факту можна вважати відсутність кореляції, наприклад, у хворих з стероїдорезистентним варіантом НФ за наявності ГВІ спостерігалось збільшення рівня обох показників при відсутності кореляції $(\mathrm{p}>0,05)$ між ними $(\rho=0,52, p=0,13)$. Аналогічна картина відмічалась у хворих на ГН з відсутністю ремісії і за наявності ГВI $(\rho=0,35, \mathrm{p}=0,11)$.

\section{ВИСНОВКИ:}

1. У хворих на ГН спостерігалось зниження рівня основного фактора місцевого імунітету - секреторного імуноглобуліну А, але при наявності ГВІ відмічалось його збільшення, в першу чергу, у хворих з нефротичною формою ГН, що свідчить про компенсаторну реакцію організму на загострення хронічного запального процесу.

2. Доведено, що діти, які страждають на ГН, характеризуються достовірним підвищенням рівня моноцитарного хемотаксичного протеїну-1 в сечі, що в більшій мірі показано у хворих з нефротичною формою ГН і $з$ ГВІ.

3. Виражений дисбаланс в місцевому імунітеті спостерігався у хворих з стероїдорезистентною формою ГН, з тяжким перебігом захворювання, а також за відсутності ремі- сії і проявлявся в найбільшому зростанні рівня sIgA та МСР-1 відносно контрольних показників, що свідчить про наявність вираженого запального процесу в нирках. Значне підвищення рівня МСР-1 в сечі у хворих на ГН може призводити до подальшого підтримання запалення і прогресування захворювання.

4. Встановлено позитивний кореляційний зв'язок між МСР-1 та sIgA у хворих на ГН, що свідчить про їх участь в формуванні місцевого імунітету, проте занадто високий початковий рівень МСР-1 може вказувати на його участь в підтримці запалення в нирках та прогресуванні гломерулонефриту. Наявність ГВІ зменшує силу взаємозв'зку між показниками, що вказує на виникнення дисбалансу в системі імунологічного захисту.

\section{ЛIТЕРАТУРА:}

1. Баринский И. Ф. Персистирующие герпесвирусные инфекции у больных хроническим гломерулонефритом / И. Ф. Баринский, Н.В.Шабалина, А. А. Никитина // Клиническая практика. - 2012. № 3. - С. 21-24.

2. Бирюков Ю. А. Гломерулонефрит у детей с НВвирусной инфекцией / Ю. А. Бирюков // Педиатрия. - 1980. - № 2. - С. 20-23.

3. Вирусная инфекция Эпштейна-Барра у больной с гормонорезистентным нефротическим синдромом: этиологический фактор или фактор прогрессирования гломерулонефрита / М. С. Игнатова, В. В. Длин, Т. А. Никишина [и др.] // Нефрология и диализ. 2005. - T.7, № 1. - С. 70-72.

4. Вирусные антигены в биоптатах почечной ткани у детей с гломерулонефритом / О. В. Катышева, А. В. Новикова, В. В. Длин [и др.] // Вопр. вирусол. - 1995. - Т.40, № 1. - С. 35-39.

5. Герпесвірусна інфекція i гломерулонефрит у дітей / В. Т. Кругліков, I. В. Багдасарова, І. В. Круглікова [та ін.] // Укр. журн. нефрології та діалізу. - 2015. - Т. 46, № 2. - С. 61-67.

6. Длин В. В. Роль вирусной инфекции в этиологии и патогенезе гломерулонефрита у детей / В. В. Длин, О. Б. Чумакова // Материалы II Российского Конгресса «Современные методы диагностики и лечения в детской нефрологии и урологии». - М., 2002. - С. 12-19.

7. Дранник Г. Н. Иммунная система слизистых, физиологическая микрофлора и пробиотики / Г. Н. Дранник, А. И. Курченко, А. Г. Дранник. ООО «Полиграф плюс», 2009. - 141 с.

8. Лопач С. Н. Статистические методы в медико-биологических исследованиях с использованием Excel / С. Н. Лопач, А. В. Чубенко, П. Н. Бабич, 2001. - 408 с.

9. Лындин А. А. Герпесвирусная инфекция и ее роль в поражении почек // Российский вестник перинатологии и педиатрии. - 2010. - Т. 55, № 6. - С. 69-77.

10. Моноцитарный хемоаттрактивный протеин-1 (MCР-1) в патогенезе изменений тубулоинтерсти- 
альной ткани у детей с хроническим гломерулонефритом / И. Е. Смирнов., А. Н. Цыгин, Т. В. Сергеева [и др.] // Нефрология и диализ. - 2005. - № 4. C. $443-447$.

11. Определение экскреции с мочой моноцитарного хемотаксического протеина-1 и трансформирующего фактора роста- $\beta 1$ у больных хроническим гломерулонефритом как метод оценки процессов фиброгенеза в почке / Н. В. Чеботарева, И. Н. Бобкова, Л. В. Козловская [и др.] // Клиническая нефрология. - 2010. - № 3. - С. 51-55.

12. Про затвердження протоколів надання медичної допомоги дітям за спеціальністю «Дитяча нефрологія» (2005). Наказ МО3 України № 365 від 20.07.2005. Київ. [Електронний ресурс]. - Режим доступу: http://moz.gov.ua/ua/portal/dn_20050720_365.html.

13. Ратнер М. Я. Гистоморфологические тубулоинтерстициальные изменения при прогрессировании хронического гломерулонефрита / М. Я. Ратнер, Н. Д. Федорова // Урология. - 2000. - № 1. - С. 28-30.

14. Реброва О. Ю. Статистический анализ медицинских данных: применение пакета прикладных программ STATISTICA / О. Ю. Реброва. - М. Медиа Сфера, 2002. -312 c.

15. Роль вирусной инфекции в патогенезе гломерулонефрита у детей. Современные подходы к иммунокорригирующей терапии / В. В. Длин, Л.Н.Горчакова, А. С. Макарян, В. В. Малиновская // Нефрология и диализ. - 2000. - Т. 2, № 4. - С. 285-289.
16. Татарова, И. В. Состояние органов мочевыделительной системы при врожденной цитомегаловирусной инфекции у детей первого года жизни // Дисс. ... канд. мед. наук. - Ставрополь, 2004. - 123 с.

17. Удосконалення діагностики герпесвірусної інфекції у хворих на гломерулонефрит: інформаційний лист / уклад. І. В. Багдасарова, С. П. Фоміна, В. Т. Кругліков, І. Г. Васильєва, І. В. Круглікова, O. I. Цюбко; МОЗ України, Укрмедпатентінформ. Київ: [б.в.], 2015. - 4 с.

18. Чеботарева H. В. Молекулярные механизмы интерстициального фиброза при прогрессировании почек (Обзор литературы) / Н. В. Чеботарева, И. Н. Бобковап, Л. В. Козловская // Нефрология и диализ. - 2006 . - Т. 8, № 1. - С. 26-35.

19. Hepatitis B virus infection and glomerulonephritis / B. R. Nammalwar, V. S. Sankar, S. Ramesh [et al.] // Ind. I. Pediatr. - 1987 - V. 54; № 5. P. 759-763.

20. Mucosal immunity in the urinary tract: changes in sIgA, FSC and total IgA with age and in urinary tract infection / M. Y. James-Ellison, R. Roberts, K. Verrier-Jones [et al.] // Clin. Nephrol. - 1997. V. 48, № 2. - P. 69-78.

21. Wada T. Chemokines: new target molecules in renal diseases / T. Wada, H. Yokoyama, K. Kobayashi // Clin. Exp. Nephrol. - 2000. - № 4. - C. 273-280.

Надійшла до редакції 18.02.2016 Прийнята до друку 26.02.2016

(C) Король Л.В., Степанова Н.М., Мігаль Л.Я., 2016

УДК 616.61-002.2-036.87:577.112

Л.В. КОРОЛЬ, Н.М. СТЕПАНОВА, Л.Я. МІГАЛЬ

СПЕЦИФІЧНІ ЗАПАЛЬНІ ПРОТЕЇНИ КРОВІ ТА СЕЧІ ХВОРИХ НА ПІЕЛОНЕФРИТ 3 РЕЦИДИВУЮЧИМ ПЕРЕБІГОМ

\author{
L. KOROL, N. STEPANOVA, L. MIGAL
}

\title{
SPECIFIC INFLAMMATORY PROTEINS IN THE BLOOD AND URINE OF PATIENTS WITH RECURRENT PYELONEPHRITIS
}

Державна установа «Інститут нефрології НАМН України», м. Київ

$$
\text { SI “Institute of Nephrology NAMS of Ukraine”, Kyiv }
$$

Ключові слова: $C$-реактивний протеїн, фібронектин, цистатин- $C$, пієлонефрит з рецидивуючим перебігом

Key words: $C$-reactive protein, fibronectin, cystatin $C$, recurrent pyelonephritis.

Резюме. Метою роботи було дослідити вміст специфічних запальних протеїнів (С-реактивний білок, фібронектин, цистатин С) у крові та сечі хворих на пієлонефрит залежсно від частоти рецидивів захворювання.

Пацієнти та методи. В одномоментне поперечне дослідження було включено 64 хворих на хронічну хворо-

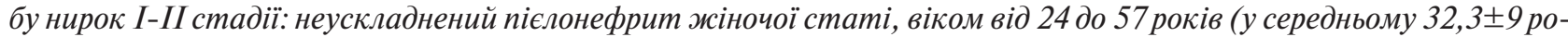
ків). Імунотурбідіметричним методом за допомогою тест систем «Dialab» (Aвстрія) у крові та сечі пацієнток визначали рівень С-реактивного білку (СРБ), фібронек-

Степанова Наталя Михайлівна nmstep@ukr.net тину (ФН) та иистатину С (ЦС). I - основну групу $(n=34)$ склали жінки з рецидивуючим перебігом пієлонефриту ( $\geq 3$ рецидивів протягом року), II - $(n=30)$ пацієнтки спорадичним перебігом захворювання (до 2 разів на рік). 